\title{
Adiponectin and resistin: potential metabolic signals affecting hypothalamo-pituitary gonadal axis in females and males of different species
}

\author{
Agnieszka Rak ${ }^{1}$ Namya Mellouk², Pascal Froment ${ }^{2}$ and Joëlle Dupont ${ }^{2}$ \\ ${ }^{1}$ Department of Physiology and Toxicology of Reproduction, Institute of Zoology, Jagiellonian University in Krakow, \\ Krakow, Poland and 'INRA, UMR 85 Physiologie de la Reproduction et des Comportements, Nouzilly, France \\ Correspondence should be addressed to J Dupont; Email: joelle.dupont@inra.fr
}

\begin{abstract}
Adipokines, including adiponectin and resistin, are cytokines produced mainly by the adipose tissue. They play a significant role in metabolic functions that regulate the insulin sensitivity and inflammation. Alterations in adiponectin and resistin plasma levels, or their expression in metabolic and gonadal tissues, are observed in some metabolic pathologies, such as obesity. Several studies have shown that these two hormones and the receptors for adiponectin, AdipoR1 and AdipoR2 are present in various reproductive tissues in both sexes of different species. Thus, these adipokines could be metabolic signals that partially explain infertility related to obesity, such as polycystic ovary syndrome (PCOS). Species and gender differences in plasma levels, tissue or cell distribution and hormonal regulation have been reported for resistin and adiponectin. Furthermore, until now, it has been unclear whether adiponectin and resistin act directly or indirectly on the hypothalamo-pituitary-gonadal axis. The objective of this review was to summarise the latest findings and particularly the species and gender differences of adiponectin and resistin on female and male reproduction known to date, based on the hypothalamo-pituitary-gonadal axis.

Reproduction (2017) 153 R215-R226
\end{abstract}

\section{Introduction}

Many authors have observed relationships between the energy metabolism and fertility or infertility in various species, including sheep, cattle, pigs, rodents and primates. For example, in cattle selected for high milk production, high negative energy balance in the post-partum period is associated with reduced fertility (Wathes et al. 2007). In sheep, it is well known that an increase in availability of energy substrates is associated with an increase in prolificacy (Teleni et al. 1989). In pigs, it is also known that a negative energy balance and a decrease in body fat results in a reduction in litter size and viability of piglets (Quesnel et al. 2007). Clinical studies have also established some links between insulin resistance and polycystic ovarian syndrome (PCOS) (Gambineri et al. 2002). This syndrome is often associated with obesity, metabolic disorders and an imbalance of reproductive hormones in women (Dunaif \& Thomas 2001). White adipose tissue (WAT) is one of the main tissues involved in the regulation of energy balance. For a long time, this organ was considered as a simple tissue for the storage of triglycerides. However, it is now well established that white adipose tissue synthesises and secretes numerous cytokines, termed as adipokines that participate in several physiological and pathological processes, such as food intake and metabolic control, diabetes, atherosclerosis, immunity and also reproductive functions (Reverchon et al. 2014). In the present review, we describe and analyse the role of two of these adipokines, adiponectin and resistin, in the female and male hypothalamo-pituitarygonadal axis.

\section{Structure, expression and role in metabolic functions of adiponectin and resistin}

Adiponectin, also known as Acrp30, is mainly secreted by mature adipocytes. It is the most abundant adipokine in the plasma (approximately $1-50 \mu \mathrm{g} / \mathrm{mL}$ ) in various species including humans, rats, birds (chicken and turkey), pigs and dairy cows (Chabrolle et al. 2007, Hendricks et al. 2009, Nishizawa et al. 2012, Maleszka et al. 2014a, Diot et al. 2015, De Koster et al. 2016). The plasma adiponectin concentrations are inversely correlated with the adipose tissue reservoir (Kadowaki \& Yamauchi 2005, Yamauchi et al. 2014). In addition, levels of adiponectin in the plasma were significantly lower in males than those in females in humans and rodents (Nishizawa et al. 2002). One explanation is that sexual hormones such oestradiol (E2) and testosterone (T) 
could regulate the plasma adiponectin concentration (Nishizawa et al. 2002). The adiponectin gene encodes a protein (full-length adiponectin; full AdipoQ) composed of four domains: an $\mathrm{N}$-terminal signal peptide, a variable region, a collagenous domain and a globular domain at the C-terminal end (Fig. 1A). Mammalian adiponectin genes that contain three exons and two introns are highly conserved between species (Hu et al. 1996). For example, the homology between pig and mouse, rat and dog was 83, 82 and 90\% respectively (Wang et al. 2004). The shorter globular adiponectin (g AdipoQ) possesses potent biological activities that have similar properties to full AdipoQ. The circulating adiponectin is found in trimer, hexamer and high-molecular-weight (HMW) forms, the latter is considered the metabolically bioactive form. Two distinct main receptors (AdipoRs) have been described in the literature, namely AdipoR1 (almost ubiquitously expressed, and abundantly so in skeletal muscles; binds the globular form) and AdipoR2 (predominantly expressed in the liver and WAT; binds the full-length protein) (Kadowaki \& Yamauchi 2005, Yamauchi et al. 2014). Unlike G-coupled protein receptors, AdipoRs are seven-transmembrane domain receptors with an extracellular carboxyl terminus and an intracellular amino terminus. The homology between AdipoR1 and AdipoR2 is $67 \%$ amino acid identity. Furthermore, they are structurally conserved from yeast to humans (Yamauchi et al. 2014). AdipoR signalling can be modulated by an interaction with two adaptor proteins named adaptor protein, phosphotyrosine interacting with $\mathrm{PH}$ domain and leucine zipper 1 (APPL1) and adaptor protein, phosphotyrosine interacting with $\mathrm{PH}$ domain and leucine zipper 2 (APPL2) (Yamauchi et al. 2014). Once adiponectin binds to AdipoR1, APPL1 activates various downstream signalling events associated with the adiponectin function. When AdipoR1 is inactive, APPL2 binds and inhibits the APPL1 function. However, APPL2 binding is displaced on AdipoR1 activation. It is well known that adiponectin activates different main signalling pathways in various tissues: AMP-activated protein kinase (AMPK), mitogen-activated protein kinase (MAPK): p38, extracellular signal-regulated kinases $1 / 2$ (ERK1/2), serine/threonine protein kinase (Akt) and peroxisome proliferator-activated receptor alpha (PPAR $\alpha$ ) (Kadowaki \& Yamauchi 2005, Yamauchi et al. 2014) (Fig. 1B). Many functions have been described for adiponectin: this hormone can control energy homeostasis and insulin sensitivity, and it affects the lipid metabolism, vasodilatation, atherogenic activity and reproductive functions (Kadowaki \& Yamauchi 2005, Brochu-Gaudreau et al. 2010, Yamauchi et al. 2014).

Resistin is a cysteine-rich, secretory protein, which is also known as Found in Inflammatory Zones (FIZZ) or Adipocyte Secretory Factor (ADSF) (Steppan et al. 2001) (Fig. 1A). It is produced by white and brown adipose tissues, but has also been identified in several other peripheral tissues. In adipose tissues, the production of resistin is dependent on the species. Indeed, resistin is produced by the adipocytes in mice, whereas it is predominantly expressed in macrophages in humans (Steppan et al. 2001). Human resistin is a $12.5 \mathrm{kDa}$

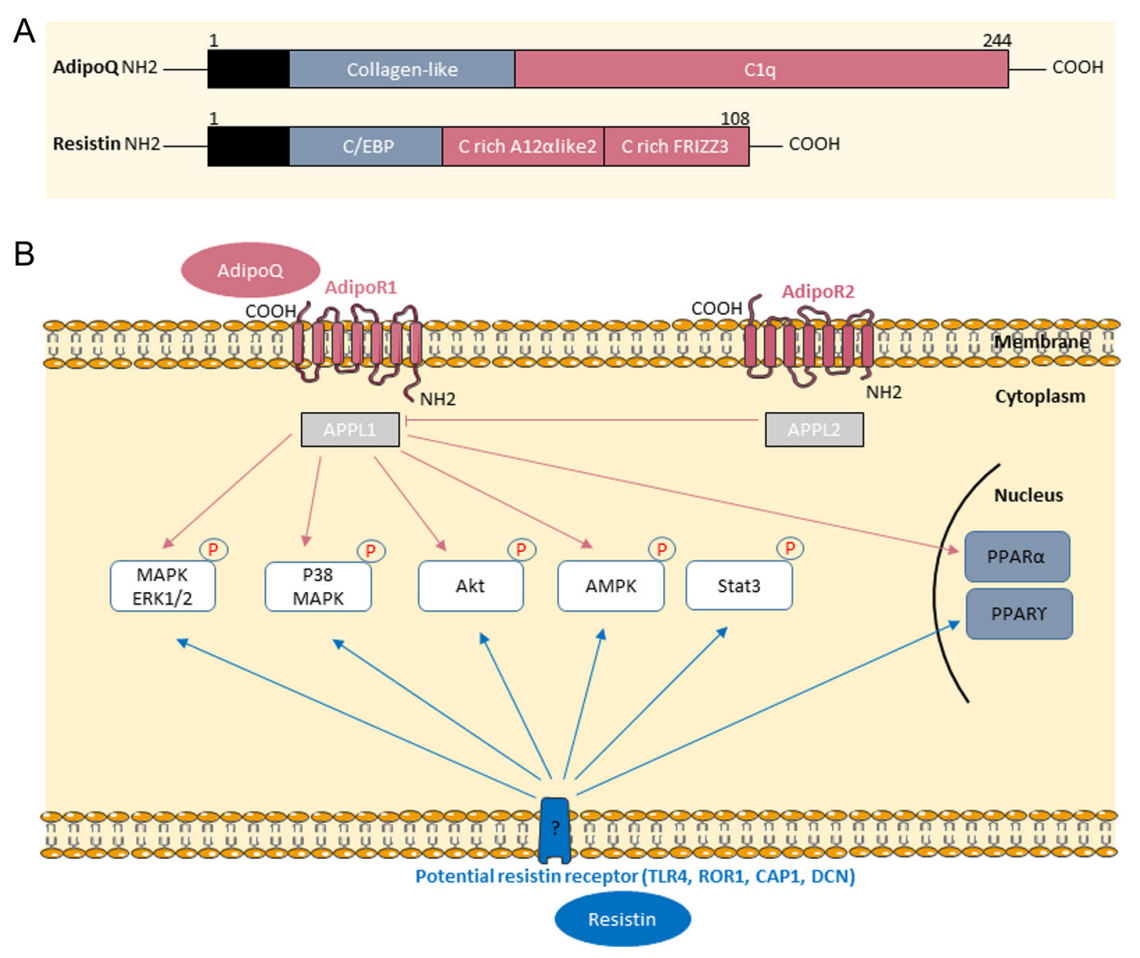

Figure 1 (A) Structure of adiponectin and resistin. (B) Signalling pathways of adiponectin receptors (AdipoR1 and AdipoR2) and resistin. AdipoQ, adiponectin; AdipoR1 and AdipoR2, adiponectin receptors; APPL1 and APPL2, adaptor proteins; PPAR $\alpha$, peroxisome proliferator-activated receptor alpha; PPAR $\gamma$, peroxisome proliferator-activated receptor gamma; AMPK, AMP-activated protein kinase; MAPK, mitogen-activated protein kinase p38; ERK1/2, extracellular signal-regulated kinases 1/2; Akt, phosphatidyl inositol 3' kinase/Akt; Stat3, signal transducer and activator of transcription 3; TLR4, toll-like receptor; ROR1, tyrosine kinase-like orphan receptor; CAP1, cyclase-associated protein 1; DCN, decorin. 
cysteine-rich peptide with a mature sequence consisting of 108 amino acids, whereas rat and mouse resistin has 114 amino acids. There is $55 \%$ amino acid identity within the mature segment of human and mouse resistin. The resistin gene is located on chromosome 19 in human, whereas it is located on chromosome 8 and 2 in mouse and pig respectively (Yang et al. 2003, Adeghate 2004). Furthermore, the human and mouse resistin genes have markedly divergent promoter regions, suggesting different mechanisms of regulation, tissue distribution and functions (Steppan et al. 2001). The comparison of amino acid sequence of bovine resistin with that of human, pig, rat and mouse showed 73, 80, 58 and 57\% identity respectively (Kang et al. 2006). The plasma and follicular fluid resistin concentrations in humans is from 5 to $50 \mathrm{ng} / \mathrm{mL}$ (Munir et al. 2005). In pigs, the resistin level in follicular fluid is approximately $0.32 \mathrm{ng} / \mu \mathrm{g}$ protein, dependent on the stage of the oestrous cycle (Rak-Mardyła et al. 2013). Resistin plasma levels are significantly higher in females when compared with males (Lee et al. 2003). The receptor of resistin remains unknown and the molecular mechanism of resistin action is unclear. However, recent reports have suggested potential receptors for resistin such as an isoform of decorin (DCN) (Daquinag et al. 2011), mouse receptor tyrosine kinase-like orphan receptor 1 (ROR1) (Sanchez-Solana et al. 2012), toll-like receptor 4 (TLR4) (Benomar et al. 2013) or adenylyl cyclase-associated protein 1 (CAP1) (Lee et al. 2014). Furthermore, it is well known that resistin activates signalling pathways in different tissues (Fig. 1B) such as Akt, MAPK (ERK1/2 and p38), Stat-3 (signal transducer and activator of transcription 3) and PPAR type gamma (PPAR $\gamma)$. Several studies have identified positive correlations between resistin levels and the pathogenesis of obesity, adipogenesis and insulin resistance (Steppan et al. 2001).

\section{Adiponectin and resistin expression and action at hypothalamus-pituitary levels}

Despite the conflicting evidence as to whether adiponectin can cross the blood-brain barrier, some studies have reported adiponectin and AdipoR expression in the brain and pituitary of various species, including humans, rats, pigs, rodents and chickens (Rodriguez-Pacheco et al. 2007, Wilkinson et al. 2007), suggesting that adiponectin may be a factor modulating the reproductive functions. AdipoRs have been identified in the hypothalamic GnRH neuron cells (GT1-7) and in human and rodent hypothalami, including in the paraventricular nucleus and in the periventricular areas. The adiponectin inhibits kisspeptin (KISS-1) gene transcription (Wen et al. 2012) and gonadotropinreleasing hormone $(\mathrm{GnRH})$ secretion (Wen et al. 2008) (Fig. 2) in GT1-7 cells.

In pigs, pituitary adiponectin levels depend on the phase of the oestrous cycle, and in vitro experiments in primary pituitary cells showed that treatment with adiponectin increases follicle-stimulating hormone (FSH) release (Kiezun et al. 2014). Conversely, the exposure of rodent pituitary cell cultures to adiponectin resulted in a reduction in luteinising hormone (LH) secretion and $\mathrm{GnRH}$-induced LH release (RodriguezPacheco et al. 2007, Lu et al. 2008). Moreover, in primary rat pituitary cells, GnRH treatment suppressed pituitary adiponectin expression (Kim et al. 2013). AdipoRs have been identified in gonadotropin-producing cells in the pars distalis but not in the pars tuberalis in the human pituitary (Wilkinson et al. 2007). To our knowledge, a sexual dimorphism has been described in the levels of circulating plasma adiponectin, with males having lower adiponectin levels than females (Arita et al. 1999). However, adiponectin levels in human cerebrospinal fluid (CFS) showed no gender difference (Kos et al. 2007).

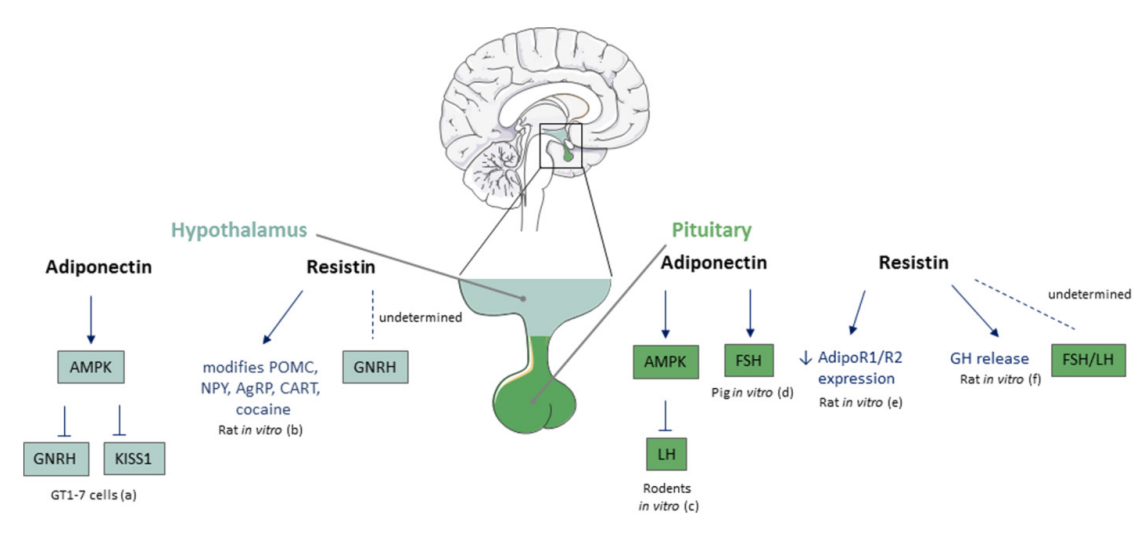

Figure 2 Effects of adiponectin and resistin on $\mathrm{GnRH}$ and $\mathrm{LH} / \mathrm{FSH}$ expression and/or secretion. $\mathrm{GnRH}$, gonadotropin-releasing hormone; $\mathrm{FSH}$, follicle-stimulating hormone; LH, luteinizing hormone; AMPK, AMPactivated protein kinase; KISS-1, kisspeptin; GT1-7, hypothalamic GnRH neuron cells; POMC, pro-opiomelanocortin; NPY, neuropeptide Y; AgRP, agouti-related peptide; CART, cocaine- and amphetamine-regulated transcript; AdipoR1/R2, adiponectin receptors; $\mathrm{GH}$, growth hormone. $\rightarrow$, activation; - inhibition. (a) Wen et al. 2008, (b) Vazquez et al. 2008, (c) RodriguezPacheco et al. 2007, Lu et al. 2008, (d) Kiezun et al. 2014, (e) Nogueiras et al. 2004, (f) Rodriguez-Pacheco et al. 2007. 
Expression of resistin has been reported in the hypothalamus of rodents (Morash et al. 2002). Resistin was identified in the human CSF with levels 100fold lower than that in the serum (Kos et al. 2007). However, its role in $\mathrm{GnRH}$ neurons remains to be determined. In the pituitary, gender differences of resistin are evident (male $>$ female at postnatal days 28 and 42), and this was not modified by neonatal treatment of female pups with T (Morash et al. 2004). Moreover, expression of resistin mRNA in the pituitary is significantly higher in prepubertal mice (Morash et al. 2002, Morash et al. 2004), whereas it increases until the age of 28 days in rats, suggesting that pituitary resistin expression is age dependent. Moreover, corticosteroids significantly increased pituitary mRNA resistin levels. It was demonstrated that the AdipoRs expression are decreased, whereas the $\mathrm{GH}$ secretion is increased after the resistin treatment in in vitro rat pituitary cells in culture (Nogueiras et al. 2004), but there is a lack of data describing the effect of resistin on gonadotropin secretion. However, Singh and coworkers have shown that serum resistin levels correlated negatively with changes in serum LH level in bats (Singh et al. 2014). In addition to the effects of adiponectin and resistin on GnRH neurons in the hypothalamus and/or on the gonadotrophs of the anterior pituitary (Fig. 2), they also affect, in a direct manner, both female and male gonads (Figs 3 and 4).

\section{Adiponectin, AdipoRs and resistin expression in the ovary}

As described in Table 1, adiponectin is not only present in the follicular fluid but also in ovarian cells of various species. In granulosa cells, adiponectin expression is low and almost undetectable in humans, rodents and chickens, suggesting species-specific differences in ovarian expression of the adiponectin gene (Chabrolle et al. 2007, 2009, Richards et al. 2012). Adiponectin and its receptors are present in the corpus luteum (CL) of mammalian species (rat, cow and sows), including women. In bovine species, the physiological status of the ovary influences the expression pattern of adiponectin and its receptors in follicular and luteal cells (Tabandeh et al. 2010). In these species, a positive correlation is also observed between the adiponectin transcript in the ovarian cells of the dominant follicle and follicular fluid oestradiol (E2) levels, indicating an association between adiponectin and follicular dominance and oocyte competence (Tabandeh et al. 2012). In humans, ovarian adiponectin and AdipoRs expression are hormonally controlled in vivo, as suggested by an increase in adiponectin concentrations in the ovarian follicular fluid of women in response to $\mathrm{LH}$ treatment in the in vitro fertilisation procedure (Gutman et al. 2009). Gonadotrophins modify the expression levels of AdipoR2, but not AdipoR1 and eventually contribute to the enhanced $3 \beta$-hydroxysteroid dehydrogenase (3ßHSD) activity and increased progesterone (P4) secretion in human granulosa cells (Wickham et al. 2013). Furthermore, after pregnant mare serum gonadotropin (PMSG) pre-treatment, an injection of human chorionic gonadotropin (hCG) increases the expression of adiponectin and AdipoR1 (but not AdipoR2) genes in rat ovaries (Chabrolle et al. 2007). Also, in bovine theca interna cells, LH increases the concentrations of AdipoR2 mRNAs, whereas insulin-like growth factor type 1 (IGF1) suppresses the expression of AdipoR2 (Lagaly et al. 2008). Steroids could also affect adiponectin expression. Indeed, in swine, adiponectin

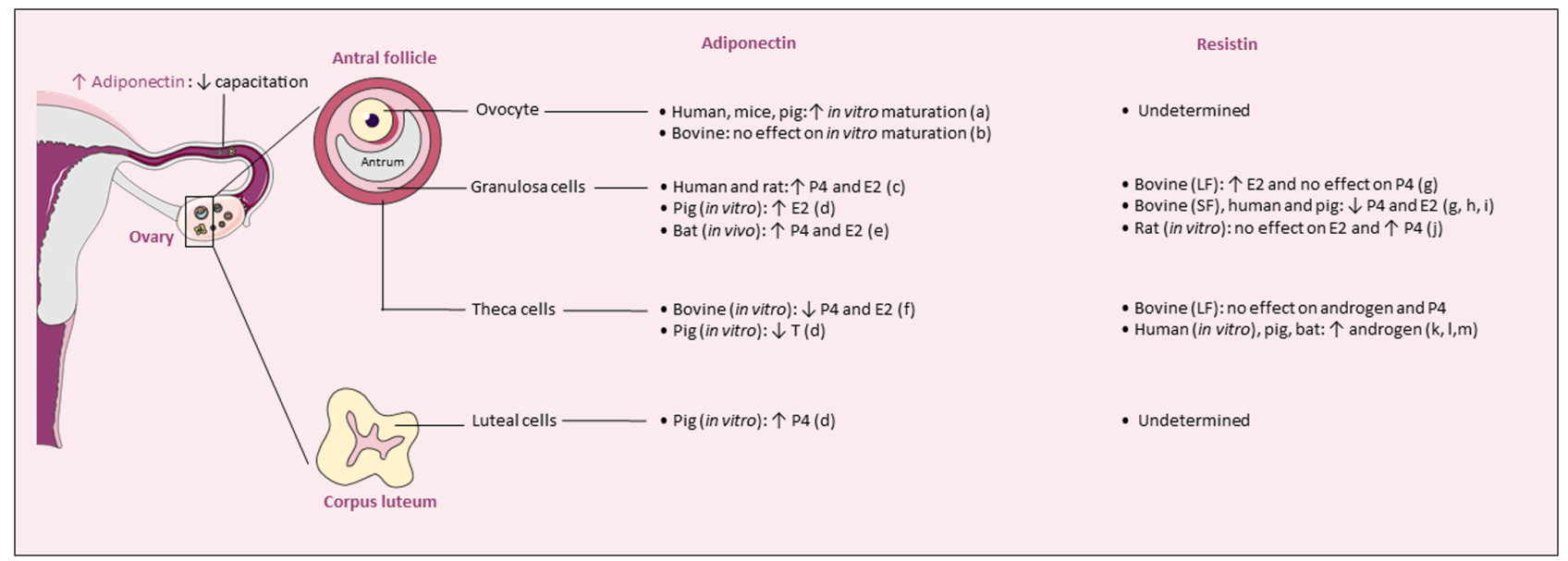

Figure 3 Effects of adiponectin and resistin on granulosa, theca and oocyte function (steroidogenesis, proliferation and apoptosis, oocyte maturation) in different species. P4, progesterone; T, testosterone; E2, estradiol; SF, small follicles; LF, large follicles. $\uparrow$, increase, $\downarrow$ decrease. (a) Richards et al. 2012, (b) Maillard et al. 2010, (c) Chabrolle et al. 2007, 2009, (d) Maleszka et al. 2014, (e) Anuradha et al. 2014, (f) Lagaly et al. 2008, (g) Spicer et al. 2011, (h) Reverchon et al. 2013, (i) Rak et al. 2015a, (j) Maillard et al. 2011, (k) Munir et al. 2005, (I) Rak-Mardyła et al. 2013, 2014, (m) Singh et al. 2015. 


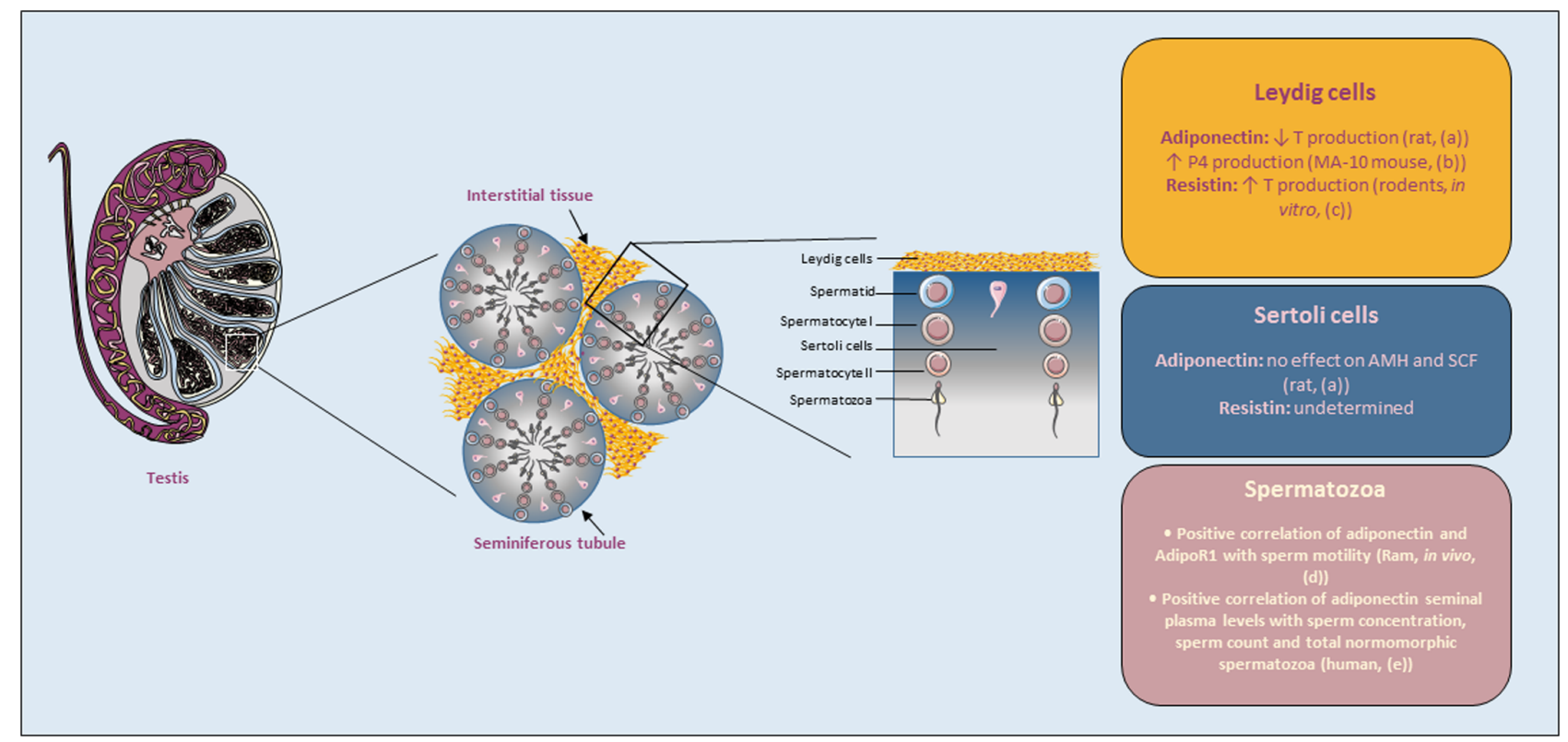

Figure 4 Effects of adiponectin and resistin on testicular cell functions (steroidogenesis, proliferation, apoptosis, sperm motility) in different species. P4, progesterone; T, testosterone; AMH, anti-Mullerian hormone; SCF, stem cell factor. (a) Caminos et al. 2008, (b) Landry et al. 2015, (c) Nogueiras et al. 2004, (d) Kadivar et al. 2016, (e) Thomas et al. 2013.

serum concentrations are higher during the luteal phase than the follicular phase, which suggests that ovarian steroids influence plasma adiponectin levels (Maleszka et al. 2014b). However, it remains to be demonstrated whether steroids can locally affect ovarian adiponectin production. Adiponectin can also influence the expression of its receptors differently according to the ovarian cell type. For example, AdipoRs expressions are increased in the cumulus-oocyte complex, but not in granulosa cells (Richards et al. 2012).

Similar to adiponectin, resistin is expressed in the ovarian cells of various species (Table 1). Niles and coworkers have demonstrated the resistin expression in human granulosa cells derived from the preovulatory follicles of females undergoing oocyte retrieval during in vitro fertilisation, suggesting its role in the follicular development (Niles et al. 2012). Resistin is also present in human granulosa cells, cumulus cells and human ovarian granulosa tumour-derived cell line (KGN), as well as in theca cells in large follicles and oocytes in the primary follicles (Reverchon et al. 2013). In bovine species, resistin is widely expressed in different-sized follicles (small $<6 \mathrm{~mm}$ and large $>6 \mathrm{~mm}$ ) where it is localised in oocytes, cumulus, theca and granulosa cells. In addition, it is present in the CL (Maillard et al. 2011). Interestingly, resistin mRNA was undetectable in rat granulosa cell cultures (Maillard et al. 2011). 'Speciesspecific' ovarian resistin expression could contribute to different effects on ovarian follicle functions, such as steroidogenesis and proliferation, as described for adiponectin. In pig ovaries, resistin levels and expression depend on the stage of the animal reproductive status; differences were observed in the expression and concentration of resistin in follicular fluid collected from small follicles (SFs), medium follicles (MFs) and large follicles (LFs) (Rak-Mardyła et al. 2013). Interestingly, in contrast to prepubertal animals, resistin expression and concentration in adult oestrous cycling pigs was independent of follicular size and/or development (RakMardyła et al. 2014). Moreover, several hormones can influence ovarian resistin expression. For example, Rak and coworkers reported that gonadotropin and steroid hormone increased, but IGF1 dose-dependent significantly decreased the ovarian resistin mRNA and protein expression in pigs (Rak et al. 2015a). In addition, the resistin ovarian expression was decreased by rosiglitazone-a PPAR $\gamma$ agonist (Rak-Mardyła \& Drwal 2016).

\section{Adiponectin and resistin in vitro effects on ovarian steroidogenesis and cell survival}

The ovarian follicles synthesise steroid hormones that control and maintain female sexual development, behaviour and pregnancy, as well as having important local effects within the ovary. The role of adiponectin has been studied in vitro in the steroidogenesis of granulosa and theca cells in several species (Fig. 3). In rats and in women, recombinant adiponectin at physiological doses $(5$ or $10 \mu \mathrm{g} / \mathrm{mL}$ ) increases the secretion of steroids in IGF1-stimulated cells (Chabrolle et al. 2007, 2009). In rats, this increase is due to increased signalling of the 
Table 1 Expression of resistin, adiponectin, AdipoR1 and AdipoR2 in ovarian and testicular cells in different species (+: presence; ns: no study).

\begin{tabular}{|c|c|c|c|c|c|c|c|c|}
\hline \multirow{2}{*}{$\begin{array}{l}\text { Adipokine or } \\
\text { receptor }\end{array}$} & \multirow[b]{2}{*}{ Species } & \multicolumn{3}{|c|}{ Ovarian cells } & \multicolumn{3}{|c|}{ Testicular cells } & \multirow[b]{2}{*}{ References } \\
\hline & & Granulosa & Theca & Oocyte & Sertoli & Leydig & Germinal & \\
\hline \multirow[t]{7}{*}{ Resistin } & Human & + & + & + & ns & ns & $\mathrm{ns}$ & $\begin{array}{l}\text { Nogueiras et al. (2004), Maillard et al. (2011), } \\
\text { Niles et al. (2012), Reverchon et al. (2013), } \\
\text { Rak-Mardyła et al. (2014), Singh et al. (2015) }\end{array}$ \\
\hline & Cattle & + & + & + & ns & ns & ns & \\
\hline & Rodents & + & + & + & + & + & ns & \\
\hline & Pig & + & + & ns & ns & ns & ns & \\
\hline & Birds & ns & ns & ns & ns & ns & ns & \\
\hline & Fish & ns & ns & ns & ns & ns & ns & \\
\hline & Bat & + & + & + & ns & ns & $\mathrm{ns}$ & \\
\hline \multirow[t]{7}{*}{ Adiponectin } & Human & + & ns & ns & ns & ns & ns & $\begin{array}{l}\text { Caminos et al. 2008, Chabrolle et al. (2007, } \\
\text { 2009), Nishio et al. (2008), Ocón-Grove et al. } \\
\text { (2008), Maillard et al. (2010), Maleszka et al. } \\
\text { (2014), Gregoraszczuk et al. (2016) }\end{array}$ \\
\hline & Cattle & + & + & + & ns & ns & ns & \\
\hline & Rodents & + & + & + & + & + & + & \\
\hline & Pig & + & + & ns & ns & ns & ns & \\
\hline & Birds & + & + & ns & + & + & + & \\
\hline & Fish & \multicolumn{3}{|c|}{ Whole ovary: + } & ns & ns & ns & \\
\hline & Bat & ns & ns & ns & ns & ns & ns & \\
\hline \multirow[t]{7}{*}{ AdipoR1 } & Human & + & + & ns & ns & ns & ns & $\begin{array}{l}\text { Chabrolle et al. (2007, 2009), Nishio et al. (2008), } \\
\text { Ocón-Grove et al. (2008), Maillard et al. (2010), } \\
\text { Comim et al. (2013), Maleszka et al. (2014), } \\
\text { Gregoraszczuk et al. (2016) }\end{array}$ \\
\hline & Cattle & + & + & + & ns & ns & ns & \\
\hline & Rodents & + & + & + & + & + & + & \\
\hline & Pig & + & + & ns & ns & ns & ns & \\
\hline & Birds & + & + & ns & + & + & + & \\
\hline & Fish & \multicolumn{3}{|c|}{ Whole ovary: + } & ns & ns & ns & \\
\hline & Bat & ns & ns & ns & ns & ns & ns & \\
\hline \multirow[t]{7}{*}{ AdipoR2 } & Human & + & + & ns & ns & ns & ns & $\begin{array}{l}\text { Chabrolle et al. (2007, 2009), Nishio et al. (2008), } \\
\text { Ocón-Grove et al. (2008), Maillard et al. (2010), } \\
\text { Comim et al. (2013), Maleszka et al. (2014), } \\
\text { Gregoraszczuk et al. (2016) }\end{array}$ \\
\hline & Cattle & + & + & + & ns & ns & ns & \\
\hline & Rodents & + & + & + & + & + & + & \\
\hline & Pig & + & + & ns & ns & ns & ns & \\
\hline & Birds & + & + & ns & + & + & + & \\
\hline & Fish & \multicolumn{3}{|c|}{ Whole ovary: + } & ns & ns & ns & \\
\hline & Bat & ns & ns & ns & ns & ns & ns & \\
\hline
\end{tabular}

IGF1 receptor and, in women, it is due to an increase in the expression of the CYP19A1 (cytochrome P450 aromatase) enzyme responsible for the oestrogen biosynthesis. In bats, adiponectin at physiological doses $(5$ and $10 \mu \mathrm{g} / \mathrm{mL}$ ) in vivo during the period of delayed development causes a significant increase in circulating P4 and E2 levels, together with an increased expression of AdipoR1 in the ovary. In this species, the effects of adiponectin on ovarian steroidogenesis are mediated through increased expression of $\mathrm{LH}$ receptor, steroidogenic acute regulatory protein and $3 \beta$-HSD (Anuradha \& Krishna 2014). In KGN cell lines, specific inactivation of AdipoRs shows that AdipoR1 regulated cell survival, whereas AdipoR2 is preferentially involved in steroidogenesis (Pierre et al. 2009). In cows, adiponectin at dose $3 \mu \mathrm{g} / \mathrm{mL}$ in vitro decreases the production of androstenedione (A4) by theca cells by reducing the expression of $\mathrm{LH}$ receptors and CYP11A1 (cytochrome P450, family 11, subfamily a, polypeptide 1) and CYP17 $\alpha 1$ (cytochrome P450, family 17 , subfamily a, polypeptide 1 ) enzymes mediated by both AdipoR1 and AdipoR2 (Lagaly et al. 2008). These data were confirmed by Comim and coworkers showing that knockdown of AdipoRs or the downstream effector protein APPL1 leads to an increase in the secretion of androstenedione (Comim et al. 2013). Thus, adiponectin differentially regulates the expression of steroidogenic enzymes in ovarian cells in various species.

The first study showed that treatment with $10 \mathrm{ng} /$ $\mathrm{mL}$ of resistin increased the androgen production by stimulation of CYP17 mRNA expression in human theca cells in vitro (Munir et al. 2005) (Fig. 3). Spicer and coworkers demonstrated that $30 \mathrm{ng} / \mathrm{mL}$ of resistin weakly stimulated FSH plus IGF1-induced E2 production, but had no effect on IGF1- or insulin-induced P4 and A4 production by theca cells or $\mathrm{P} 4$ production by granulosa cells of LFs (Spicer et al. 2011). However, in granulosa cells from SFs, resistin attenuated the stimulatory effect 
of IGF1 on P4 and E2 secretion. In vitro treatment with resistin on bovine granulosa cells showed a decreased basal, but not IGF1-induced P4 and E2 production. Although in cultured rat granulosa cells, basal and IGF1-induced P4 secretion increased after the treatment with a physiological dose $(10 \mathrm{ng} / \mathrm{mL})$ of resistin, with no effects on E2 release (Maillard et al. 2011). Similarly, studies on human granulosa cells treated with resistin have also shown reduced steroid hormone secretion in response to IGF1 (Reverchon et al. 2013). However, in human theca cells in normal cycling premenopausal women (Munir et al. 2005), pig ovary (Rak-Mardyła et al. 2013, 2014) and bats (Singh et al. 2015), a stimulatory effect of resistin at physiological doses on androgen production was observed. Conversely, in porcine ovarian follicles, resistin decreased gonadotropinand IGF1-induced steroid hormone secretion by inhibiting the protein expressions of $3 \beta \mathrm{HSD}, 17 \beta \mathrm{HSD}$ and CYP19A1 (Rak et al. 2015a). These contradictory findings may be explained by the presence of various isoforms of resistin, which may explain the functional diversity of resistin in different species. Thus, the resistin receptor remains unknown, and resistin action in ovarian steroidogenesis mechanism remains unclear. However, Rak-Mardyła and Drwal demonstrated that in cultured porcine ovarian follicles, PPAR $\gamma$ is the key regulator of resistin expression and steroidogenic function (Rak-Mardyła \& Drwal 2016). Maillard and coworkers clearly documented that in cultured bovine and rat granulosa cells $10 \mathrm{ng} / \mathrm{mL}$ of resistin stimulated the phosphorylation of different kinases such as Akt, MAPKs, P38 and ERK1/2. Furthermore, Reverchon and coworkers demonstrated that resistin decreased the IGF1-induced tyrosine phosphorylation of the IGF1R $\beta$ subunit and phosphorylation of MAPK ERK1/2 and suggested that the MAPK ERK1/2 signalling pathway regulated in vitro steroidogenesis in primary human granulosa cells (Reverchon et al. 2013). Recently, Singh and coworkers showed that resistin injection in bats $(6.5 \mu \mathrm{g} / 100 \mathrm{~g}$ body weight/day for 12 days) increased Stat-3 phosphorylation in the ovaries. Similarly, in cultured porcine ovarian cells, resistin $(10 \mathrm{ng} / \mathrm{mL})$ activated not only the phosphorylation of Stat-3 but also MAPK ERK1/2 and Akt (Rak et al. 2015b).

Apoptosis is critically important for the survival of multicellular organisms by getting rid of damaged or infected cells that may interfere with normal ovarian function such as oogenesis, folliculogenesis, oocyte loss/selection and atresia. Several pro-survival and proapoptotic molecules are involved in ovarian apoptosis with the delicate balance between them being the determinant for the final destiny of the follicular cells. In bovine species, adiponectin at a concentration of $10 \mu \mathrm{g} / \mathrm{mL}$ increases in vitro IGF1-induced granulosa cell proliferation but not basal or insulin-induced proliferation (Maillard et al. 2010). In the basal state, similar effects of adiponectin have been described on the proliferation of LF theca cells. In primary human granulosa cells, treatment with adiponectin at a concentration of $5 \mu \mathrm{g} /$ $\mathrm{mL}$ does not affect the IGF1-induced cell proliferation (Chabrolle et al. 2009). The published in vitro data concerning ovarian cell proliferation showed some effects dependent on the resistin doses; no effect at the lower, physiological doses ( 1 and $10 \mathrm{ng} / \mathrm{mL}$ ) in pigs (Rak et al. 2015b) and rats (Maillard et al. 2011), whereas stimulated effects were observed at higher doses (100; 333 and $667 \mathrm{ng} / \mathrm{mL}$ ). Similarly, in vivo, resistin induced a stimulatory effect on the expression of proliferating cell nuclear antigen (PCNA) in the ovaries of seasonally monoestrous bats (Singh et al. 2014). However, in vitro, resistin reduced $\left[{ }^{3} \mathrm{H}\right]$ thymidine incorporation in response to IGF-I in rat granulosa cells (Maillard et al. 2011). The previously mentioned observations indicated that resistin, depending on doses and animal models, has different actions on ovarian cell proliferation, which is an important process in the ovarian function.

In the in vivo ovaries of bats, resistin decreased protein levels but stimulated caspase-3 activity. Similarly, in pig ovary, resistin decreased pro-apoptotic genes expression, caspase activity and DNA fragmentation (Rak et al. 2015b). As a molecular mechanism of resistin action on cell survival, authors have proposed the activation of several signal transduction pathways such as MAPK/ ERK1/2, JAK/STAT and PI3K (Rak et al. 2015b). These results show that resistin is involved in ovarian apoptosis regulation and could regulate follicular development or atresia.

\section{Adiponectin and resistin effects on oocytes}

As described previously, adiponectin and AdipoRs are present in the oocytes of different species (Table 1 ). In in vitro fertilisation protocols in women, mice and pigs, but not in cows, adiponectin at physiological doses improved oocyte maturation and early embryo development (Chappaz et al. 2008, Maillard et al. 2010, Richards et al. 2012) (Fig. 3). In adiponectin-deficient mice, the number of ovulated oocytes drastically decreased as compared with controls with similar body weight (Table 2). However, no experiments to date have specifically inhibited adiponectin and AdipoRs expression in different ovarian cells to determine the involvement of systemic and ovarian adiponectin. In addition, there are no data about the role of resistin in oocyte maturation. These should form the basis of future studies.

\section{Adiponectin, AdipoRs and resistin expressions in testes}

In humans, adiponectin concentration in seminal plasma is approximately 66-fold lower than that in serum, and a positive correlation with sperm concentration, 
Table 2 Consequences of targeted or non-targeted disruption or overexpression of resistin, adiponectin, AdipoR1 and AdipoR2 on the fertility and reproductive axis in mice.

\begin{tabular}{|c|c|c|c|c|}
\hline Components & Tissue/cell type & Effect on fertility & Reproductive axis consequences & References \\
\hline Resistin & All & Fertile & & $\begin{array}{l}\text { Pravenec et al. (2003), } \\
\text { Banerjee et al. (2004) }\end{array}$ \\
\hline Adiponectin & All & Female subfertility & $\begin{array}{l}\text { Reduction in retrieval of oocytes, } \\
\text { disruption of the estrous cycle, } \\
\text { elevated number of atretic } \\
\text { follicles, reduction in } \\
\text { progesterone, oestradiol and FSH } \\
\text { plasma levels, in concentration } \\
\text { of LH surge, and in GnRH } \\
\text { immunoreactive neurons }\end{array}$ & Cheng et al. (2016) \\
\hline Adiponectin & $\begin{array}{l}\text { Overexpression dominant } \\
\text { negative lacking collagen } \\
\text { domain using promoter } \\
\text { ap2 (adipose tissue) }\end{array}$ & Infertile & $\begin{array}{l}\text { One of the line displayed 3-fold } \\
\text { increased serum adiponectin } \\
\text { levels, and was unfertile }\end{array}$ & Combs et al. (2004) \\
\hline Adiponectin & All & Fertile & & $\begin{array}{l}\text { Ma et al. (2002), } \\
\quad \text { Nawrocki et al. (2006) }\end{array}$ \\
\hline AdipoR1 & All & Fertile (male and female) & & Yamauchi et al. (2007) \\
\hline AdipoR1 and AdipoR2 & All & Fertile (male and female) & & Yamauchi et al. (2007) \\
\hline AdipoR2 & All & Male subfertility & $\begin{array}{l}\text { An atrophy of the seminiferous } \\
\text { tubules and aspermia associated } \\
\text { with reduced testes weight }\end{array}$ & $\begin{array}{l}\text { Bjursell et al. (2007), } \\
\text { Lindgren et al. (2013) }\end{array}$ \\
\hline AdipoR2 & All & Fertile (male and female) & & Yamauchi et al. (2007) \\
\hline
\end{tabular}

sperm count and total normomorphic spermatozoa has been reported (Thomas et al. 2013). Heinz and coworkers (Heinz et al. 2015) have concluded that in cattle, adiponectin concentration in seminal plasma is likely blood borne and originates from adipose tissues. Therefore, the potential contribution of local secretion from the testes, if any, is only marginal. In rats, adiponectin is mainly present in the Leydig interstitial cells, whereas AdipoR1 is expressed in the seminiferous tubules (Caminos et al. 2008).

Nogueiras and coworkers (Nogueiras et al. 2004) showed that mRNA expression of resistin in rat testes was higher in the Leydig interstitial cells than that in the Sertoli cells within seminiferous tubules, and this expression was regulated by gonadotropins, leptins and nutritional status. Resistin is also expressed in the mouse Leydig cell lines (MA-10 and TM3) and exposure to 8-Br-cAMP (8-Bromoadenosine 3', $5^{\prime}$-cyclic monophosphate) increased its mRNA expression in MA-10 Leydig cells (Jean et al. 2012). Moretti and coworkers (Moretti et al. 2014) showed that in humans, the resistin level was higher in semen than that in serum, and that semen resistin correlated with the sperm quality.

\section{Adiponectin and resistin in vitro effects on testes function}

Adiponectin treatment decreases the production of $\mathrm{T}$ in the presence or absence of hCG in the rat testicular tissue, whereas it has no effect on the expression of the genes encoding anti-Mullerian hormone $(\mathrm{AMH})$ and stem cell factor (SCF) that are specific to the Sertoli cells (Caminos et al. 2008) (Fig. 4). However, in MA-10 mouse Leydig cells, adiponectin treatment improves
P4 production through an increase in the cholesterol carrier StAR and the CYP11A1 steroidogenesis enzyme, suggesting that high doses of adiponectin (50, 500, or $5000 \mathrm{ng} / \mathrm{mL}$ ) could promote $\mathrm{T}$ production from the Leydig cells (Landry et al. 2015). In mice, AdipoR2 deficiency results in atrophy of seminiferous tubules and aspermia without a change in $\mathrm{T}$ concentration (Bjursell et al. 2007) (Table 2). In chickens, studies show an increase in the testicular adiponectin receptors during sexual maturation and suggest a role for adiponectin in steroidogenesis, spermatogenesis, Sertoli cell function and sperm motility (Ocon-Grove et al. 2008). In rams, adiponectin and AdipoR1 mRNA expressions are positively correlated with sperm motility (Kadivar et al. 2016). In bulls, adiponectin and its receptors also play vital roles in the structural and functional sperm traits by regulating sperm capacitation (Kasimanickam et al. 2013).

To our knowledge, there are limited data on resistin action on testicular cells function. Resistin significantly increased basal and hCG-stimulated $\mathrm{T}$ secretion in rat incubated testicular tissues (Nogueiras et al. 2004). Exposure to low concentrations of resistin $(10 \mathrm{ng} / \mathrm{mL})$, corresponding to a normal physiological condition, contributes to an increased proliferation of MA-10 Leydig cells (Jean et al. 2012). In addition, the Sertoli cells may also contribute to the Leydig cells proliferation by secreting resistin (Nogueiras et al. 2004). Thus, adiponectin and resistin signalling appears to be present in male gonadal tissues, but the extent to which these hormones contribute to normal human testicular function and fertility potential remains to be determined. In addition to their role in steroidogenesis, adiponectin and resistin could be 
involved in sperm capacitation, sperm-egg fusion and fertilisation.

\section{Role of adiponectin and resistin in vivo in mice fertility}

Although many studies have reported in vitro effects of adiponectin and resistin on ovarian and testicular cell functions, the involvement of these two adipokines in vivo to control the fertility remains unclear. Several studies have shown that adiponectin-null mice are viable and, in studies where fertility outcomes are mentioned, appear to exhibit normal fertility (Ma et al. 2002, Nawrocki et al. 2006) (Table 2). However, overexpression of adiponectin leads to increased insulin sensitivity and infertility or subfertility (Combs et al. 2004), and a recent study demonstrated that disruption of adiponectin can cause subfertility in female mice (Cheng et al. 2016). Indeed, female adiponectin-null mice displayed reduced retrieval of oocytes, a disrupted oestrous cycle, an elevated number of atretic follicles and impaired late folliculogenesis (Table 2). Also, their serum has lower levels of P4 at dioestrus that can be explained by a lower expression of CYP11A1 and a significant reduction in E2 and $\mathrm{FSH}$ at pro-oestrus. Adiponectin deficiency also altered the hypothalamopituitary axis, as the plasma peak concentrations of $\mathrm{LH}$ surged and the number of $\mathrm{GnRH}$ immunoreactive neurons was significantly reduced. Concerning AdipoRs, their genetic deletion was not associated with subfertility in one study (Yamauchi et al. 2007), but a loss of AdipoR2 was associated with male subfertility in other studies (Bjursell et al. 2007, Lindgren et al. 2013). Disruption of AdipoR2 in males leads to seminiferous tubules atrophy and aspermia associated with reduced testes weight. Various studies where resistin protein levels were increased in different peripheral tissues (such as adipose tissue or liver) did not report any effect on fertility (Pravenec et al. 2003, Banerjee et al. 2004).

Thus, these data indicate that adiponectin signalling is important to normal mouse female and male reproduction. However, the role of this adipokine specifically in each gonadal cell remains to be determined. Concerning resistin, however, much less is known about its involvement in in vivo reproductive function and, therefore, this remains to be investigated.

\section{Potential involvement of adiponectin and resistin in some pathologies associated with gonadal dysfunctions such as PCOS}

PCOS is a metabolic disorder in humans that is linked to insulin resistance and obesity. It is characterised by anovulation, hyperandrogenism and hyperinsulinemia (Dunaif \& Thomas 2001). Excessive production of insulin in women in PCOS, with its subsequent induction of theca cell steroidogenesis, is thought to be the primary cause of hyperandrogenism.

Adipokines such as adiponectin and resistin could act as a link between obesity and PCOS (Spritzer et al. 2015). Many studies have investigated the concentration of adiponectin and resistin in both plasma and follicular fluid in patients with PCOS and control groups. However, data are still controversial (Spritzer et al. 2015). Several studies have documented a lack of any difference in resistin concentration in serum or follicular fluid of patients with PCOS when compared to the control groups, even though serum adiponectin was significantly lower in obese than that in normalweight women. However, Munir and coworkers have suggested that resistin is involved in PCOS because the concentration of resistin was significantly increased in patients with PCOS and was positively correlated with body mass index and T levels. Concerning adiponectin, some authors have also analysed the different forms of adiponectin in patients with PCOS and they observed that there were low levels of HMW adiponectin in both serum and follicular fluid of PCOS patients with controlled ovarian hyperstimulation compared to controls (Artimani et al. 2016). Furthermore, the expression pattern of the adiponectin system (adiponectin, AdipoRs and APPL1) has been studied in patients with PCOS, and a reduction of APPL1 and the adiponectin system was observed in human granulosa cells (Dehghan et al. 2016). Furthermore, recently Yuan and coworkers showed that brown adipose tissue (BAT) transplantation activated endogenous BAT and increased the circulating level of adiponectin in a dehydroepiandrosterone (DHEA)-induced PCOS rat (Yuan et al. 2016). Comim and coworkers also showed that a lower proportion of theca cells expressed AdipoRs in polycystic ovaries than that in normal ovaries (Comim et al. 2013). Many studies have also described the association of PCOS with polymorphisms of the adiponectin or adiponectin receptor genes. The resistin gene polymorphism is associated with body mass index in women with PCOS, suggesting that resistin might be related to adiposity in PCOS.

\section{Conclusions}

In conclusion, resistin, adiponectin and AdipoRs are present and active in the hypothalamo-pituitary-gonadal axis. Their expressions can be regulated by various factors (such as gender, age, nutritional and hormonal status). Many in vitro studies have shown that these two adipokines can regulate gonadal steroidogenesis and gametogenesis. Adiponectin can also exert effects on $\mathrm{GnRH}$ synthesis and the pituitary secretory functions that could then indirectly affect gonadal functions. The in vitro effects of resistin on $\mathrm{GnRH}$ and gonadotropin secretion are still unknown. In mice, adiponectin deficiency leads to female subfertility associated 
with ovarian and hypothalamo-pituitary dysfunction and AdipoR2 deficiency leads to male subfertility with aspermia and atrophy of tubules, suggesting an important role of the adiponectin system in the normal reproduction. If these data are confirmed in human and other species, adiponectin or its analogues (recombinant adiponectin, adiponectin receptor agonist) could be used in the treatment of certain infertilities, similar to how they are used in the metabolic syndrome. Furthermore, whether these in vivo adipokine effects act directly on the hypothalamo-pituitary-gonadal axis needs to be studied. For example, mice with targeted disruption of the adiponectin system or resistin in ovarian and testicular cells could be developed to analyse the metabolic and reproductive phenotypes. Finally, the role of other adipokines (visfatin, chemerin, omentin and so forth) in reproductive diseases related to insulin resistance and obesity should be investigated.

\section{Declaration of interest}

The authors declare that there is no conflict of interest that could be perceived as prejudicing the impartiality of this review.

\section{Funding}

The support was received from the Campus France and Ministry of Science and Higher Education in Poland for the PHC project under the bilateral Polish-France Agreement 'POLONIUM' (2016-2017).

\section{References}

Adeghate E 2004 An update on the biology and physiology of resistin. Cellular and Molecular Life Sciences 61 2485-2496. (doi:10.1007/ s00018-004-4083-2)

Anuradha \& Krishna A 2014 Modulation of ovarian steroidogenesis by adiponectin during delayed embryonic development of Cynopterus sphinx. Journal of Steroid Biochemistry and Molecular Biology 143 291-305. (doi:10.1016/j.jsbmb.2014.04.009)

Arita Y, Kihara S, Ouchi N, Takahashi M, Maeda K, Miyagawa J, Otta K, Shimomura I, Nakamura T, Miyaoka K et al. 1999 Paradoxical decrease of an adipose-specific protein, adiponectin, in obesity. Biochemical and Biophysical Research Communications 257 79-83. (doi:10.1006/ bbrc.1999.0255)

Artimani T, Saidijam M, Aflatoonian R, Ashrafi M, Amiri I, Yavangi M, SoleimaniAsl S, Shabab N, Karimi J \& Mehdizadeh M 2016 Downregulation of adiponectin system in granulosa cells and low levels of HMW adiponectin in PCOS. Journal of Assisted Reproduction and Genetics 33 101-110. (doi:10.1007/s10815-015-0620-1)

Banerjee RR, Rangwala SM, Shapiro JS, Rich AS, Rhoades B, Qi Y, Wang J, Rajala MW, Pocai A, Scherer PE et al. 2004 Regulation of fasted blood glucose by resistin. Science 303 1195-1198. (doi:10.1126/ science.1092341)

Benomar Y, Gertler A, De Lacy P, Crepin D, Ould Hamouda H, Riffault L \& Taouis M 2013 Central resistin overexposure induces insulin resistance through Toll-like receptor 4. Diabetes 62 102-114. (doi:10.2337/db120237)

Bjursell M, Ahnmark A, Bohlooly YM, William-Olsson L, Rhedin M, Peng XR, Ploj K, Gerdin AK, Arnerup G, Elmgren A et al. 2007 Opposing effects of adiponectin receptors 1 and 2 on energy metabolism. Diabetes 56 583-593. (doi:10.2337/db06-1432)
Brochu-Gaudreau K, Rehfeldt C, Blouin R, Bordignon V, Murphy BD \& Palin MF 2010 Adiponectin action from head to toe. Endocrine 37 11-32. (doi:10.1007/s12020-009-9278-8)

Caminos JE, Nogueiras R, Gaytan F, Pineda R, Gonzalez CR, Barreiro ML, Castano JP, Malagon MM, Pinilla L, Toppari J et al. 2008 Novel expression and direct effects of adiponectin in the rat testis. Endocrinology 149 3390-3402. (doi:10.1210/en.2007-1582)

Chabrolle C, Tosca L \& Dupont J 2007 Regulation of adiponectin and its receptors in rat ovary by human chorionic gonadotrophin treatment and potential involvement of adiponectin in granulosa cell steroidogenesis. Reproduction 133 719-731. (doi:10.1530/REP-06-0244)

Chabrolle C, Tosca L, Rame C, Lecomte P, Royere D \& Dupont J 2009 Adiponectin increases insulin-like growth factor I-induced progesterone and estradiol secretion in human granulosa cells. Fertility and Sterility 92 1988-1996. (doi:10.1016/j.fertnstert.2008.09.008)

Chappaz E, Albornoz MS, Campos D, Che L, Palin MF, Murphy BD \& Bordignon V 2008 Adiponectin enhances in vitro development of swine embryos. Domestic Animal Endocrinology 35 198-207. (doi:10.1016/j. domaniend.2008.05.007)

Cheng L, Shi H, Jin Y, Li X, Pan J, Lai Y, Lin Y, Jin Y, Roy G, Zhao A et al. 2016 Adiponectin deficiency leads to female subfertility and ovarian dysfunctions in mice. Endocrinology 157 4875-4887. (doi:10.1210/ en.2015-2080)

Combs TP, Pajvani UB, Berg AH, Lin Y, Jelicks LA, Laplante M, Nawrocki AR, Rajala MW, Parlow AF, Cheeseboro L et al. 2004 A transgenic mouse with a deletion in the collagenous domain of adiponectin displays elevated circulating adiponectin and improved insulin sensitivity. Endocrinology 145 367-383. (doi:10.1210/en.2003-1068)

Comim FV, Hardy K \& Franks S 2013 Adiponectin and its receptors in the ovary: further evidence for a link between obesity and hyperandrogenism in polycystic ovary syndrome. PLOS ONE 8 e80416. (doi:10.1371/ journal.pone.0080416)

Daquinag AC, Zhang Y, Amaya-Manzanares F, Simmons PJ \& Kolonin MG 2011 An isoform of decorin is a resistin receptor on the surface of adipose progenitor cells. Cell Stem Cell 9 74-86. (doi:10.1016/j. stem.2011.05.017)

De Koster J, Urh C, Hostens M, Van den Broeck W, Sauerwein H \& Opsomer G 2016 Relationship between serum adiponectin concentration, body condition score, and peripheral tissue insulin response of dairy cows during the dry period. Domestic Animal Endocrinology 59 100-104. (doi:10.1016/j.domaniend.2016.12.004)

Dehghan R, Saidijam M, Mehdizade M, Shabab N, Yavangi M \& Artimani T 2016 Evidence for decreased expression of APPL1 associated with reduced insulin and adiponectin receptors expression in PCOS patients. Journal of Endocrinological Investigation 39 1075-1082. (doi:10.1007/ s40618-016-0468-y)

Diot $M$, Reverchon $M$, Rame $C$, Froment $P$, Brillard JP, Brière S, Levêque $G$, Guillaume D \& Dupont J 2015 Expression of adiponectin, chemerin and visfatin in plasma and different tissues during a laying season in turkeys. Reproductive Biology and Endocrinology 31 13-81. (doi:10.1186/ s12958-015-0081-5)

Dunaif A \& Thomas A 2001 Current concepts in the polycystic ovary syndrome. Annual Review of Medicine 52 401-419. (doi:10.1146/ annurev.med.52.1.401)

Gambineri A, Pelusi C, Vicennati V, Pagotto U \& Pasquali R 2002 Obesity and the polycystic ovary syndrome. International Journal of Obesity and Related Metabolic Disorders 26 883-896. (doi:10.1038/sj.ijo.0801994)

Gregoraszczuk E, Slupecka M, Wolinski J, Hejmej A, Bilinska B, Fiedor E, Piwnicka N \& Rak A 2016 Maternal high-fat diet during pregnancy and lactation had gender difference effect on adiponectin in rat offspring. Journal of Physiology and Pharmacology 201667 543-553.

Gutman G, Barak V, Maslovitz S, Amit A, Lessing JB \& Geva E 2009 Recombinant luteinizing hormone induces increased production of ovarian follicular adiponectin in vivo: implications for enhanced insulin sensitivity. Fertility and Sterility 91 1837-1841. (doi:10.1016/j. fertnstert.2008.02.006)

Hendricks GL 3rd, Hadley JA, Krzysik-Walker SM, Prabhu KS, VasilatosYounken R \& Ramachandran R 2009 Unique profile of chicken adiponectin, a predominantly heavy molecular weight multimer, and relationship to visceral adiposity. Endocrinology $\mathbf{1 5 0} 3092-3100$. (doi:10.1210/en.2008-1558)

Heinz JF, Singh SP, Janowitz U, Hoelker M, Tesfaye D, Schellander K \& Sauerwein H 2015 Characterization of adiponectin concentrations 
and molecular weight forms in serum, seminal plasma, and ovarian follicular fluid from cattle. Theriogenology 83 326-333. (doi:10.1016/j. theriogenology.2014.06.030)

Hu E, Liang P \& Spieglman BM 1996 AdipoQ is a novel adipose-specific gene dysregulated in obesity. Journal of Biological Chemistry 271 10697-10703. (doi:10.1074/jbc.271.18.10697)

Jean S, Landry D, Daigle M \& Martin LJ 2012 Influence of the adipose derived hormone resistin on STAT factors, steroidogenesis and proliferation of Leydig cells. Asian Pacific Journal of Reproduction 1 1-6. (doi:10.1016/S2305-0500(13)60038-X)

Kadivar A, Heidari Khoei H, Hassanpour H, Golestanfar A \& Ghanaei H 2016 Correlation of adiponectin mRNA abundance and its receptors with quantitative parameters of sperm motility in rams. International Journal of Fertility and Sterility 10 127-135.

Kadowaki T \& Yamauchi T 2005 Adiponectin and adiponectin receptors. Endocrine Reviews 26 439-451. (doi:10.1210/er.2005-0005)

Kasimanickam VR, Kasimanickam RK, Kastelic JP \& Stevenson JS 2013 Associations of adiponectin and fertility estimates in Holstein bulls. Theriogenology 79 766-777. e761-e763. (doi:10.1016/j. theriogenology.2012.12.001)

Kang HK, Park JA, Seo KS, Kim SH, Choi YJ \& Moon YS 2006 Characteristics of structure and expression pattern of ADSF/resistin gene in Korean native cattle Asian-Aust. Animal Science Journal 19 329-334. (doi:10.5713/ ajas.2006.329)

Kiezun M, Smolinska N, Maleszka A, Dobrzyn K, Szeszko K \& Kaminski T 2014 Adiponectin expression in the porcine pituitary during the estrous cycle and its effect on LH and FSH secretion. American Journal of Physiology: Endocrinology and Metabolism 307 E1038-E1046. (doi:10.1152/ajpendo.00299.2014)

Kim J, Zheng W, Grafer C, Mann ML \& Halvorson LM 2013 GnRH decreases adiponectin expression in pituitary gonadotropes via the calcium and PKA pathways. Reproductive Sciences 20 937-945. (doi:10.1177/1933719112468947)

Kos K, Harte AL, da Silva NF, Tonchev A, Chaldakov G, James S, Snead DR, Hoggart B, O'Hare JP, McTernan PG et al. 2007 Adiponectin and resistin in human cerebrospinal fluid and expression of adiponectin receptors in the human hypothalamus. Journal of Clinical Endocrinology and Metabolism 92 1129-1136. (doi:10.1210/jc.2006-1841)

Lagaly DV, Aad PY, Grado-Ahuir JA, Hulsey LB \& Spicer LJ 2008 Role of adiponectin in regulating ovarian theca and granulosa cell function. Molecular and Cellular Endocrinology 284 38-45. (doi:10.1016/j. mce.2008.01.007)

Landry D, Pare A, Jean S \& Martin LJ 2015 Adiponectin influences progesterone production from MA-10 Leydig cells in a dose-dependent manner. Endocrine 48 957-967. (doi:10.1007/s12020-014-0456-y)

Lee JH, Chan JL, Yiannakouris N, Kontogianni M, Estrada E, Seip R, Orlova C \& Mantzoros CS 2003 Circulating resistin levels are not associated with obesity or insulin resistance in humans and are not regulated by fasting or leptin administration: cross-sectional and interventional studies in normal, insulin-resistant, and diabetic subjects. Journal of Clinical Endocrinology and Metabolism 88 4848-4856. (doi:10.1210/jc.2003-030519)

Lee S, Lee HC, Kwon YW, Lee SE, Cho Y, Kim J, Lee S, Kim JY, Lee J, Yang HM et al. 2014 Adenylyl cyclase-associated protein 1 is a receptor for human resistin and mediates inflammatory actions of human monocytes. Cell Metabolism 19 484-497. (doi:10.1016/j.cmet.2014.01.013)

Lindgren A, Levin M, Rodrigo Blomqvist S, Wikstrom J, Ahnmark A, Mogensen C, Bottcher G, Bohlooly YM, Boren J, Gan LM et al. 2013 Adiponectin receptor 2 deficiency results in reduced atherosclerosis in the brachiocephalic artery in apolipoprotein E deficient mice. PLOS ONE 8 e80330. (doi:10.1371/journal.pone.0080330)

Lu M, Tang Q, Olefsky JM, Mellon PL \& Webster NJ 2008 Adiponectin activates adenosine monophosphate-activated protein kinase and decreases luteinizing hormone secretion in LbetaT2 gonadotropes. Molecular Endocrinology 22 760-771. (doi:10.1210/me.2007-0330)

Ma K, Cabrero A, Saha PK, Kojima H, Li L, Chang BH, Paul A \& Chan L 2002 Increased beta-oxidation but no insulin resistance or glucose intolerance in mice lacking adiponectin. Journal of Biological Chemistry 277 34658-34661. (doi:10.1074/jbc.C200362200)

Maillard V, Uzbekova S, Guignot F, Perreau C, Rame C, CoyralCastel S \& Dupont J 2010 Effect of adiponectin on bovine granulosa cell steroidogenesis, oocyte maturation and embryo development.
Reproductive Biology and Endocrinology 8 23. (doi:10.1186/14777827-8-23)

MaillardV, Froment P, Rame C, Uzbekova S, Elis S \& Dupont J 2011 Expression and effect of resistin on bovine and rat granulosa cell steroidogenesis and proliferation. Reproduction 141 467-479. (doi:10.1530/REP-10-0419)

Maleszka A, Smolinska N, Nitkiewicz A, Kiezun M, Dobrzyn K, Czerwinska J, Szeszko K \& Kaminski T 2014a Expression of adiponectin receptors 1 and 2 in the ovary and concentration of plasma adiponectin during the oestrous cycle of the pig. Acta Veterinaria Hungarica 62 386-396. (doi:10.1556/AVet.2014.007)

Maleszka A, Smolinska N, Nitkiewicz A, Kiezun M, Chojnowska K, Dobrzyn K, Szwaczek H \& Kaminski T 2014b Adiponectin expression in the porcine ovary during the oestrous cycle and its effect on ovarian steroidogenesis. International Journal of Endocrinology 2014957076. (doi:10.1155/2014/957076)

Morash BA, Willkinson D, Ur E \& Wilkinson M 2002 Resistin expression and regulation in mouse pituitary. FEBS Letters 526 26-30. (doi:10.1016/ S0014-5793(02)03108-3)

Morash BA, Ur E, Wiesner G, Roy J \& Wilkinson M 2004 Pituitary resistin gene expression: effects of age, gender and obesity. Neuroendocrinology 79 149-156. (doi:10.1159/000077273)

Moretti E, Collodel G, Mazzi L, Campagna M, lacoponi F \& Figura N 2014 Resistin, interleukin-6, tumor necrosis factor-alpha, and human semen parameters in the presence of leukocytospermia, smoking habit, and varicocele. Fertility and Sterility 102 354-360. (doi:10.1016/j. fertnstert.2014.04.017)

Munir I, Yen HW, Baruth T, Tarkowski R, Azziz R, Magoffin DA \& Jakimiuk AJ 2005 Resistin stimulation of 17alpha-hydroxylase activity in ovarian theca cells in vitro: relevance to polycystic ovary syndrome. Journal of Clinical Endocrinology and Metabolism 90 4852-4857. (doi:10.1210/ jc.2004-2152)

Nawrocki AR, Rajala MW, Tomas E, Pajvani UB, Saha AK, Trumbauer ME, Pang Z, Chen AS, Ruderman NB, Chen H et al. 2006 Mice lacking adiponectin show decreased hepatic insulin sensitivity and reduced responsiveness to peroxisome proliferator-activated receptor gamma agonists. Journal of Biological Chemistry 281 2654-2660. (doi:10.1074/ jbc.M505311200)

Niles LP, Lobb DK, Kang NH \& Armstrong KJ 2012 Resistin expression in human granulosa cells. Endocrine 42 742-745. (doi:10.1007/s12020012-9734-8)

Nishio S, Gibert Y, Bernard L, Brunet F, Triqueneaux G \& Laudet V 2008 Adiponectin and adiponectin receptor genes are coexpressed during zebrafish embryogenesis andregulated by food deprivation. Developmental Dynamics 237 1682-1690. (doi:10.1002/dvdy.21559)

Nishizawa H, Shimomura I, Kishida K, Maeda N, Kuriyama H, Nagaretani H, Matsuda M, Kondo H, Furuyama N, Kihara S et al. 2002 Androgens decrease plasma adiponectin, an insulin-sensitizing adipocyte-derived protein. Diabetes 51 2734-2741. (doi:10.2337/diabetes.51.9.2734)

Nogueiras R, Barreiro ML, Caminos JE, Gaytan F, Suominen JS, Navarro VM, Casanueva FF, Aguilar E, Toppari J, Dieguez C et al. 2004 Novel expression of resistin in rat testis: functional role and regulation by nutritional status and hormonal factors. Journal of Cell Science 117 3247-3257. (doi:10.1242/jcs.01196)

Ocon-Grove OM, Krzysik-Walker SM, Maddineni SR, Hendricks GL 3rd \& Ramachandran R 2008 Adiponectin and its receptors are expressed in the chicken testis: influence of sexual maturation on testicular ADIPOR1 and ADIPOR2 mRNA abundance. Reproduction 136 627-638. (doi:10.1530/REP-07-0446)

Pierre P, Froment $\mathbf{P}$, Negre D, Rame C, Barateau V, Chabrolle C, Lecomte $\mathbf{P}$ \& Dupont J 2009 Role of adiponectin receptors, AdipoR1 and AdipoR2, in the steroidogenesis of the human granulosa tumor cell line, KGN. Human Reproduction 24 2890-2901. (doi:10.1093/humrep/dep292)

Pravenec M, Kazdova L, Landa V, Zidek V, Mlejnek P, Jansa P, Wang J, Qi N \& Kurtz TW 2003 Transgenic and recombinant resistin impair skeletal muscle glucose metabolism in the spontaneously hypertensive rat. Journal of Biological Chemistry 278 45209-45215. (doi:10.1074/jbc. M304869200)

Quesnel H, Etienne M \& Pere MC 2007 Influence of litter size on metabolic status and reproductive axis in primiparous sows. Animal Science Journal 85 118-128. (doi:10.2527/jas.2006-158)

Rak-Mardyła A \& Drwal E 2016 In vitro interaction between resistin and peroxisome proliferator-activated receptor gamma in porcine 
ovarian follicles. Reproduction Fertility and Development 28 357-368. (doi:10.1071/RD14053)

Rak-Mardyła A, Durak M \& Lucja Gregoraszczuk E 2013 Effects of resistin on porcine ovarian follicle steroidogenesis in prepubertal animals: an in vitro study. Reproductive Biology and Endocrinology 1145. (doi:10.1186/1477-7827-11-45)

Rak-Mardyła A, Duda M \& Gregoraszczuk EL 2014 A role for resistin in the ovary during the estrous cycle. Hormone and Metabolic Research $\mathbf{4 6}$ 493-498. (doi:10.1055/s-0034-1370909)

Rak A, Drwal E, Karpeta A \& Gregoraszczuk EL 2015a Regulatory role of gonadotropins and local factors produced by ovarian follicles on in vitro resistin expression and action on porcine follicular steroidogenesis. Biology of Reproduction 92 142. (doi:10.1095/biolreprod.115.128611)

Rak A, Drwal E, Wrobel A \& Gregoraszczuk EL 2015b Resistin is a survival factor for porcine ovarian follicular cells. Reproduction 150 343-355. (doi:10.1530/REP-15-0255)

Reverchon M, Cornuau M, Rame C, Guerif F, Royere D \& Dupont J 2013 Resistin decreases insulin-like growth factor I-induced steroid production and insulin-like growth factor I receptor signaling in human granulosa cells. Fertility and Sterility 100 247-255. e241-e243. (doi:10.1016/j. fertnstert.2013.03.008)

Reverchon M, Ramé C, Bertoldo M \& Dupont J 2014 Adipokines and the female reproductive tract. International Journal of Endocrinology 2014 232454. (doi:10.1155/2014/232454)

Richards JS, Liu Z, Kawai T, Tabata K, Watanabe H, Suresh D, Kuo FT, Pisarska MD \& Shimada M 2012 Adiponectin and its receptors modulate granulosa cell and cumulus cell functions, fertility, and early embryo development in the mouse and human. Fertility and Sterility $98471-$ 479. e471. (doi:10.1016/j.fertnstert.2012.04.050)

Rodriguez-Pacheco F, Martinez-Fuentes AJ, Tovar S, Pinilla L, TenaSempere M, Dieguez C, Castano JP \& Malagon MM 2007 Regulation of pituitary cell function by adiponectin. Endocrinology 148 401-410. (doi:10.1210/en.2006-1019)

Sanchez-Solana B, Laborda J \& Baladron V 2012 Mouse resistin modulates adipogenesis and glucose uptake in 3T3-L1 preadipocytes through the ROR1 receptor. Molecular Endocrinology 26 110-127. (doi:10.1210/ me.2011-1027)

Singh A, Suragani M \& Krishna A 2014 Effects of resistin on ovarian folliculogenesis and steroidogenesis in the vespertilionid bat, Scotophilus heathi. General and Comparative Endocrinology 208 73-84. (doi:10.1016/j.ygcen.2014.09.005)

Singh A, Suragani M, Ehtesham NZ \& Krishna A 2015 Localization of resistin and its possible roles in the ovary of a vespertilionid bat, Scotophilus heathi. Steroids 95 17-23. (doi:10.1016/j.steroids. 2014.12.018)

Spicer LJ, Schreiber NB, Lagaly DV, Aad PY, Douthit LB \& GradoAhuir JA 2011 Effect of resistin on granulosa and theca cell function in cattle. Animal Reproduction Science 124 19-27. (doi:10.1016/j. anireprosci.2011.01.005)

Spritzer PM, Lecke SB, Satler F \& Morsch DM 2015 Adipose tissue dysfunction, adipokines, and low-grade chronic inflammation in polycystic ovary syndrome. Reproduction 149 R219-R227. (doi:10.1530/REP-14-0435)

Steppan CM, Bailey ST, Bhat S, Brown EJ, Banerjee RR, Wright CM, Patel HR, Ahima RS \& Lazar MA 2001 The hormone resistin links obesity to diabetes. Nature 409 307-312. (doi:10.1038/35053000)

Tabandeh MR, Hosseini A, Saeb M, Kafi M \& Saeb S 2010 Changes in the gene expression of adiponectin and adiponectin receptors (AdipoR1 and AdipoR2) in ovarian follicular cells of dairy cow at different stages of development. Theriogenology 73 659-669. (doi:10.1016/j. theriogenology.2009.11.006)

Tabandeh MR, Golestani N, Kafi M, Hosseini A, Saeb M \& Sarkoohi P 2012 Gene expression pattern of adiponectin and adiponectin receptors in dominant and atretic follicles and oocytes screened based on brilliant cresyl blue staining. Animal Reproduction Science 131 30-40. (doi:10.1016/j.anireprosci.2012.02.006)
Teleni E, Rowe JB, Croker KP, Murray PJ \& King WR 1989 Lupins and energy-yielding nutrients in ewes. II. Responses in ovulation rate in ewes to increased availability of glucose, acetate and amino acids. Reproduction Fertility and Development 1 117-125. (doi:10.1071/ RD9890117)

Thomas S, Kratzsch D, Schaab M, Scholz M, Grunewald S, Thiery J, Paasch U \& Kratzsch J 2013 Seminal plasma adipokine levels are correlated with functional characteristics of spermatozoa. Fertility and Sterility 99 1256-1263.e1253. (doi:10.1016/j.fertnstert.2012.12.022)

Vázquez MJ, González CR, Varela L, Lage R, Tovar S, Sangiao-Alvarellos S, Williams LM, Vidal-Puig A, Nogueiras R, López M et al. 2008 Central resistin regulates hypothalamic and peripheral lipid metabolism in a nutritional-dependent fashion. Endocrinology 149 4534-4543. (doi:10.1210/en.2007-1708)

Wang PH, Ko YH, Liu BH, Peng HM, Lee MY, Chen CY, Liand YC \& Ding ST 2004 The expression of porcine adiponectin and stearoyl coenzyme a desaturase genes in differentiating adipocytes. Asian-Australasian Animal Science Journal 17 588-593. (doi:10.5713/ajas.2004.588)

Wathes DC, Fenwick M, Cheng Z, Bourne N, Llewellyn S, Morris DG, Kenny D, Murphy J \& Fitzpatrick R 2007 Influence of negative energy balance on cyclicity and fertility in the high producing dairy cow. Theriogenology 68 (Supplement 1) S232-S241. (doi:10.1016/j. theriogenology.2007.04.006)

Wen JP, Liu C, Bi WK, Hu YT, Chen Q, Huang H, Liang JX, Li LT, Lin LX \& Chen G 2012 Adiponectin inhibits KISS1 gene transcription through AMPK and specificity protein-1 in the hypothalamic GT1-7 neurons. Journal of Endocrinology 214 177-189. (doi:10.1530/JOE-12-0054)

Wen JP, Lv WS, Yang J, Nie AF, Cheng XB, Yang Y, Ge Y, Li XY \& Ning G 2008 Globular adiponectin inhibits GnRH secretion from GT17 hypothalamic GnRH neurons by induction of hyperpolarization of membrane potential. Biochemical and Biophysical Research Communications 371 756-761. (doi:10.1016/j.bbrc.2008.04.146)

Wickham EP 3rd, Tao T, Nestler JE \& McGee EA 2013 Activation of the $\mathrm{LH}$ receptor up regulates the type 2 adiponectin receptor in human granulosa cells. Journal of Assisted Reproduction and Genetics 30 963-968. (doi:10.1007/s10815-013-0012-3)

Wilkinson M, Brown R, Imran SA \& Ur E 2007 Adipokine gene expression in brain and pituitary gland. Neuroendocrinology 86 191-209. (doi:10.1159/000108635)

Yamauchi T, Nio Y, Maki T, Kobayashi M, Takazawa T, Iwabu M, OkadaIwabu M, Kawamoto S, Kubota N, Kubota T et al. 2007 Targeted disruption of AdipoR1 and AdipoR2 causes abrogation of adiponectin binding and metabolic actions. Nature Medicine 13 332-339. (doi:10.1038/nm1557)

Yamauchi T, Iwabu M, Okada-Iwabu M \& Kadowaki T 2014 Adiponectin receptors: a review of their structure, function and how they work. Best Practice and Research Clinical Endocrinology and Metabolism 28 15-23. (doi:10.1016/j.beem.2013.09.003)

Yang RZ, Huang Q, Xu A, McLenithan JC, Eisen JA, Shuldiner AR, Alkan S \& Gong DW 2003 Comparative studies of resistin expression and phylogenomics in human and mouse. Biochemical and Biophysical Research Communications 310 927-935. (doi:10.1016/j. bbrc.2003.09.093)

Yuan X, Hu T, Zhao H, Huang Y, Ye R, Lin J, Zhang C, Zhang H, Wei G, Zhou $\mathbf{H}$ et al. 2016 Brown adipose tissue transplantation ameliorates polycystic ovary syndrome. PNAS 113 2708-2713. (doi:10.1073/ pnas.1523236113)

Received 2 January 2017

First decision 3 February 2017

Revised manuscript received 14 March 2017

Accepted 22 March 2017 